Mitja Krajnčan, Nina Stenko

mitja.krajncan@guest.arnes.si

nina.stenko@siol.net

(Pedagoška fakulteta Univerze v Ljubljani)

\title{
KAZEN V SLOVENSKI OSNOVNI ŠOLI
}

\section{POVZETEK}

Članek ponuja kritičen pogled na vedno znova vroč kostanj v šoli, imenovan kazen. Šolsko kazen pregleda skozi zgodovinski diskurz usmerjen predvsem od obdobja, ko se je kazen pričela humanizirati. Vprašanje o smiselnosti kazni, njeni ustreznosti ali nuji predstavljajo osrednji del teoretskega diskurza. Restitucijo vidimo kot dober pristop v kaznovanju, brez katerega si je težko predstavljati ustrezno socializacijo v šolskem prostoru, katere v postmoderni morajo šoli pomeniti pomemben izziv.

V raziskavi ugotavljamo kako se kazen, če se, pojavlja v slovenski osnovni šoli, katere kazni prevladujejo, kakšen vzroke za kaznovanje pripisujejo učenke/ci, kakšnega učitelji/ce in svetovalne/i delavke/ ci. Pri kaznovalnih ukrepih smo se osredinili na Strmčnikovo razdelitev kaznovanja (kategorija upravno - administrativnih, moralno obsojajočih, poravnalnih, omejitvenih, osramotitvenih, verbalnih in telesne kazni) in na učinkovitost omenjenih kazni.

S svetovalnimi delavkami smo opravili intervjuje, kjer smo želeli umestiti še njihovo vlogo in videnje v dinamiki kaznovanja in kazni v osnovni šoli.

KLJUČNE BESEDE: Kazen, kaznovanje, osnovana šola, restitucija, disciplina, učenka/ec, učitelj/ica. 


\section{Teoretske predpostavke}

Ke azen je bila vedno pomemben del vzgoje, hkrati pa vedno znova spodbuja polemike pedagogov tako preteklih stoletij kot tudi vzgojiteljev moderne dobe. V različnih zgodovinskih obdobjih se je nanjo gledalo z različnih zornih kotov: z upanjem, da bo kot čudežni prašek ozdravila mladino neprimernega vedenja, s strahom, kakšne posledice bo pustila ter z mešanimi občutki, mogoče pa ima vendarle več pozitivnih kot negativnih učinkov? Očitno vsakokratni čas prinaša s seboj malike in neustrezne reakcije ter odzive v pedagoških situacijah, ki postavljajo dileme razvoju vzgojnih konceptov in njenemu razvoju.

Kazen in disciplina sta še vedno torišče mnogih razhajanj.

Šola opravlja poleg družine temeljno socializacijsko funkcijo. Čeprav je osnovna šola le del razvejanega šolskega sistema, predstavlja poseben člen v tem sistemu. V osnovni šoli se udejanja osnova vzgoje in izobraževanja.

Za ohranjanje odnosov v šoli so potrebna pravila in tudi kazni za kršenje le-teh. V družbi in šoli, kot njenem produktu, nenehno poteka kaznovanje, ki se je tekom zgodovine spreminjalo in humaniziralo. Šolsko kaznovanje se je (od časov terezijanskih reform dalje, ko je šola postala obvezna in tudi množično obiskana), kot sredstvo "krotenja" in kot vzgojno sredstvo zelo razvilo.

$\mathrm{V}$ začetkih javne osnovne šole je bila šiba pogost učiteljev pripomoček. Poglavitna skrivnost vzgoje v 19. stoletju je po mnenju Puharjeve (2004) skrita v palici, poglavitna vzgojna metoda pa pretepanje. Vendar palica ni bila edino, niti najhujše sredstvo za vbijanje učenosti v glavo. Šele v drugi polovici 19. stoletja je nadomestila druge, hujše sramotilne kazni, kot so bile prenašanje lesenega osla okoli vratu, pretepanje po goli zadnjici, uporaba korobača in bičev. Učitelj je bil tudi pri uporabi palice zelo grob. Udarci so padali po celem telesu: glavi, obrazu, rokah, nogah, plečih, odprtih dlaneh. Pogosto se je v šoli lasalo, klofutalo, navijalo ušesa.

Telesno kaznovanje je bilo avgusta 1870. leta z ukazom Ministrstva za bogočastje in uk prepovedano. Takšen je bil zakon, samo učiteljstvo pa je bilo še v veliki večini mnenja, da je telesna kazen v šoli še kako potrebna, in se je zavzemalo za ponovno uzakonjenje le-te.
Sčasoma se je v pedagoško miselnost vrinila ideja, ki se je, kljub nasprotovanju zloglasnemu 24. členu, ki je prepovedal palico, počasi vedno bolj utrjevala in sicer: dober učitelj je tisti, ki čim manj kaznuje. Tem bolj se je 19. stoletje nagibalo v drugo polovico, tem več je bilo nasprotnikov pretepanja.

V šoli ureja vedenje učitelja in učenca cela vrsta disciplinskih pravil. Poleg občih, šolskih pisanih pravil, ki veljajo v vseh šolah, obstaja še cela vrsta posebnih internih pravil, ki veljajo samo v nekaterih šolah. Tovrstna pravila pomembno vplivajo na šolsko klimo, saj določajo celotno delovanje zaposlenih in šolarjev. Določajo govor, gibanje, čas in odnos med učiteljem in učencem. V slednjem obstaja paleta nenapisanih moralnih norm, ki jih je težko racionalno utemeljiti. Saleclova (1991) našteva najpogostejša pravila v tem odnosu: pravilo ubogljivosti, pravilo lepega vedenja, zahteva po govorjenju resnice, prepoved nasilja nad učiteljem, zahteva po obveznem sodelovanju. Osnovno pravilo v odnosu učitelj - učenec je tudi zahteva, da mora učenec za vsako gibanje, govorjenje, ki ni dovoljeno, predvideno oz. ki ga ni zahteval učitelj, posebej prositi za dovoljenje.

Kakšne razultate prinaša kazen? Predvsem se je kot neutemeljeno izkazalo mnenje, da kazen pospešuje pozitivno vedenje in večjo aktivnost. Trstenjak (po Skalar, 1978) to imenuje motivacijska zmota. Kajti kazen ne motivira, od nje ne moremo pričakovati večje prizadevnosti ali bolj pozitivnega vedenja. S kaznijo po njegovem mnenju kvečjemu preprečimo nezaželeno vedenje, ga oviramo in ga potisnemo v ozadje, dokler je prisotna dejanska ali potencialna grožnja.

Celo Skinner (po Gibson, Chandler, 1988) je na številnih eksperimentih dokazoval, da ni nobena reakcija s kaznijo za vedno ali dokončno oslabljena, pač pa le začasno pritajena in če kazen izostane, se ponovno pojavlja vedenje, ki je bilo prvotno kaznovano. Za nameček ni intenzivnost kaznovanega vedenja ob ponovnem pojavljanju nič manjša kot v primeru, če kazni sploh ni bilo. Kazen tudi ne vodi k novim konstruktivnim rešitvam.

Mnogi pedagogi menijo, da se pravo vzgajanje in kaznovanje izključujeta. "Človekovo kultiviranje se ne more vršiti s silo, niti tedaj, če bi res ne imeli nikakega drugačnega sredstva" (Gogala, 2005, s. 98). Na drugi 
strani zasledimo drugačno razmišljanje nekaterih sodobnih avtorjev glede fizičnega kaznovanja, saj menijo, da postaja kazen nekaj "nezdravega", tabuiranega, četudi je včasih nujno potrebna in odsotnost le-te otroku bolj škodi kot koristi. "V sodobni družbi postaja vse večji problem dejstvo, da se otrok ne kaznuje. K temu pripomore miselnost, da je vsaka oblika kaznovanja, ki je običajno podkrepljena z izražanjem jeze, nasilja, takšna da škoduje otrokovemu razvoju" (Steiner idr., 2004, s. 56). Starši in vzgojitelji se ob kazni ne počutijo dovolj samozavestno, ne verjamejo v njen učinek. Posledica nekaznovanja je lahko, da otroci izgubijo kurs: možni izhodi so razvajenost, hiperprotektivnost, nemotiviranost, čustvene motnje... "Izogibanje kaznovanju pa lahko izvira tudi iz zmotnega stališča, da so sprejemljiva samo tista čustva, ki nam prinašajo prijetne občutke. /.../ V naši kulturi je izražanje jeze zaznamovano kot nekaj slabega /.../ dejansko pa z jezo otroku sporočamo, da je njegovo vedenje nesprejemljivo ter kako pomembno je za nas, da to vedenje spremeni" (prav tam).

Realistično je razmišljanje, da "kazen moramo sprejeti v sistem vzgoje in prevzgoje /.../ ker predstavlja vsaj za sedaj nujni sestavni del vzgojnega procesa. Toda ne vsakršna kazen in tudi ne kazen nasploh" (Skalar, 1978, s. 1f). Avtor nadaljuje, da kazni ne moremo izključiti iz vzgoje, še posebno ne tistih kazni, od katerih se pričakuje pozitivne vzgojne učinke in ki niso odtujena otroku in vzgojnim ciljem in niso same sebi namen. Seveda v pedagoški praksi ni prostora za kazni, ki izhajajo iz iracionalnih razlogov (strasti, afektov), četudi so človeško lahko razumljivi. Kroflič (2003) zagovarja trditev, da ker tako na kazen kot na problem discipliniranja in omejevanja otroka gledamo najprej s perspektive otrokovega doživljanja, se v vzgoji za oblikovanje samostojne, kritične, odgovorne in etično občutljive osebnosti tem neprijetnim vzgojnim ukrepom ne moremo izogniti, niti jim ne smemo vnaprej odreči možnost pozitivnih pedagoških učinkov.

Šola kot, sicer umetna, institucija predstavlja živ organizem, kjer nenehno potekajo odnosi na različnih relacijah. Za uspešno in nekaotično delovanje potrebuje pravila in za kršitelje teh pravil ustrezne sankcije. Zato bi bilo precej utopično misliti, da šola lahko preživi in deluje brez kakršnegakoli sistema kaznovanja. Seveda pa nikakor ne moremo sprejeti vsakršnih oblik kazni, temveč le tiste, ki so vzgojne, ki imajo ustrezen učinek.

Učiteljeva strokovna dolžnost je v osnovi izobraževalna in ne kazenska. "Vendar učitelji, kot člani družbe, niso imuni na prevladujoče kaznovalno ozračje in negativna prepričanja se lahko izrazijo ravno v trenutku, ko je učitelj pod velikim pritiskom in ko je najmanj sposoben strokovno reševati probleme" (Gray idr., 1994, s. 2). Pravilnik o pravicah in dolžnostih učencev v osnovni šoli je poskrbel za pravno - formalno varstvo otrokovih pravic. V njem niso zapisane le pravice učencev temveč tudi dolžnosti, zajema pa tudi kršitve šolskega reda in kazni, ki so za kršitve predpisane. Kroflič (2002) opozarja, da se s sprejetjem Pravilnika skušajo nekateri izogibati uporabi kazni. Pravi, da v slovenskih šolah naletimo na več primerov poskusa izogibanja kazni ter nadomeščanja tega nepriljubljenega in tabuiranega pedagoškega ukrepa z (domnevno) drugimi vzgojnimi sredstvi. V Pravilnik naj bi ravnatelji in učitelji polagali prevelika pričakovanja, saj so menili, da bo nadomestil vsa pereča vprašanja discipliniranja.

Strmčnik (1965) meni, da je težko podati neko splošno navodilo, kaj kaznovati, kajti vsak otrok je individuum zase in to mora kaznovalec upoštevati. Vendar pa učiteljem prav omenjeni Pravilnik omogoča večjo objektivnost in pravičnost odločitve, ki pa lahko privede pri manj senzibilnih tudi do šablonskega kaznovanja. Strmčnik (prav tam), glede na značaj kazenskih posledic in glede na to, kateri del učenčeve osebnosti najbolj prizadene, deli kazni v osnovni šoli na pet različnih kategorij: upravno - administrativne kazni (vpis v dnevnik, opomin, premestitev učenca $v$ drug oddelek, prešolanje), moralno obsojajoče kazni (zagovor učenca pred razredom in pogovor $\mathrm{z}$ razrednikom, pogovor učenca $\mathrm{z}$ ravnateljem, ignoriranje učenca, obvestitev in pogovor s starši), poravnalne kazni (denarna kazen, popravilo oz. zamenjava poškodovanega predmeta), omejitvene kazni (učenec mora ostati po pouku v šoli, kazenska naloga, odvzem odmora, prepoved udeležbe na šolskem izletu), kazni profaniranja (osramotitve) učenca (učenec mora stati v klopi, premestitev v drugo klop, odstranitev učenca iz razreda, učenec je za kazen vprašan za oceno, 
telesna kazen, stanje in klečanje v kotu, razni sramotilni vzdevki itd).

Kroflič (1997) meni, da je kaznovanje del šole in da se šola kot institucija in učitelj kot njen neposredni predstavnik ne moreta odreči svoji temeljni socializacijski vlogi, ki vselej temelji tudi na discipliniranju in podrejanju učenca "ustreznim" idealnim tipom osebnosti. Da bi se dokopali do vzgojnih prijemov, ki jih zares potrebujemo, se moramo po mnenju Colorosove (1996) najprej zavedati neustreznih, neučinkovitih in razdiralnih vzgojnih metod, ki jih uporabljamo. Potem se moramo notranje pripraviti na to, da ovržemo stara vzgojna pomagala in začnemo uporabljati tista, ki bodo najustrezneje služila nam in otrokom. "Za surovim ravnanjem tiči eno samo sporočilo: "Ti si slab. Slabši si od drugih. Pravzaprav si tako slab, da te lahko popravi samo trda in stroga vzgoja. In ker si tako ničvreden, si zaslužiš samo vse najslabše" (Hauck, 1988, s. 134). Za discipliniranje otrok je torej potrebno uporabiti drugačne metode, predvsem pa se moramo izogibati vsem oblikam telesnega in duševnega kaznovanja.

Moderni dobi primerna oblika discipliniranja je, po najinem mnenju, restitucija, saj se je izkazala za vzgojen način kaznovanja, ki daje kršitelju pravil priložnost, da prevzeme odgovornost ter napako popravi.

Mendler (1992) pravi, da vsi otroci potrebujejo: občutek in vero, da so lahko sposobni in uspešni; - da vedo, da skrbijo zanje; - da se zavejo, da so sposobni vplivati na ljudi in dogodke; - da se spomnijo in dejansko pomagajo soljudem s svojo širokosrčnostjo; - zabavo in spodbudo. Ko katera od zgoraj naštetih osnovnih potreb ni zadovoljena, bo otrok iskal zadovoljitev na drugačne, pogosto neadekvatne načine in pri pogosto neprimernih ljudeh (npr. v slabi družbi, na ulici). Restitucija kot način discipliniranja zadovolji otrokove potrebe (tako kršitelja, kot žrtve) in obenem spodbudi pozitivno preobrazbo.

Koncept restitucije lahko uporabimo, ko želimo opustiti tradicionalne načine discipliniranja. Restitucija ni povračilo, temveč omogoča učitelju, da preusmeri učenca in pridobi kontrolo, ne da bi uničil samospoštovanje učenca. Ko učencem damo priložnost, da napako popravijo, namesto da jih kaznujemo oz. da jih obravnavamo kot pasivne žrtve okoliščin, izgubijo strah pred napakami, saj spoznajo, da je cilj discipliniranja v tem, da poglobijo in pridobijo nova znanja. Restitucijo opredeljujejo naslednje lastnosti: žrtvi pomeni ustrezno nadomestilo; krivec se mora potruditi; restitucija ne spodbuja nadaljnjih napak. Če je restitucija izjemno uspešna, ima še naslednje značilnosti: pomembna je na področju, kjer je napaka storjena; vezana je na vrednoto, na način, kako ljudje ravnajo z drugimi ljudmi, in ne le na posamičen dogodek; utrjuje otroka. Uspešno restitucijo pa opredeljuje tudi izostanek določenega negativnega vedenja odraslih: ni kritike, občutka krivde; pri odraslem, ki nudi pomoč, ni občutka zamere ali izkoriščanosti (Chelsom Gossen, 1993). Restitucija se zdi kot dober princip, ki ubira srednjo pot med staro avtoritarno šolo in oblikami kaznovanja ter med dopuščanjem in nereagiranjem ali reagiranjem brez ustrezne pedagoške avtoritete ${ }^{1)}$.

\section{Metodologija}

\subsection{Opredlitev problema in raziskovalni cilji}

Kaznovanje kljub trendom, da bi ga bilo vedno manj, še vedno predstavlja pomembno vzgojno orodje. Tudi šola se kot vzgojno izobraževalna institucija srečuje z različnimi oblikami kaznovanja, s katerimi preprečuje nered in zagotavlja spoštovanje pravil in disciplino. Pravilnik o pravicah in dolžnostih učencev (1996) jasno opredeljuje administrativne sankcije, ki naj bi sledile določenim neprimernim vedenjem. Obenem pa pusti vnemar ostale vzgojne prijeme, ki se pojavljajo na šolah s strani učiteljev in veljajo za psihično nasilje.

$Z$ raziskavo sva želela ugotoviti, katere kazni se pojavljajo v slovenskem šolskem prostoru. Zanimala naju je pogostnost uporabe določenih kazni ter učinkovitost le-teh, kot ju vidijo učenci in učitelji. Želela sva ugotoviti kolikšna je stopnja povezanosti ocene pogostnosti uporabe ter ocene učinkovitosti določenih kazni učencev in učiteljev. Zanimali so naju vzroki za kaznovanje, kot jih opredeljujejo učitelji in na drugi strani učenci ter kam se ti dve skupini zatečeta po pomoč, ko ne vesta kako kaznovati oz. v primeru, da je bila kazen krivična. In kot

1) V praksi se zdi, da se rado zateka k zamenjevanju pedagoške nemoči z permisinim vzgojnim pristopom. 
zadnje, sva želela ugotoviti, kakšno predstavo o kaznovanju imajo šolski svetovalni delavci, kako sodelujejo pri določanju kazni ter kje vidijo pomanjkljivosti sodobnega šolskega okolja.

Za izhodišče raziskave sva si vzela naslednje trditve, ki sva jih tekom obdelave podatkov preverjala:

- Spol učenca vpliva na oceno pogostosti uporabe nekaterih kazni.

- Spol učenca vpliva na oceno učinkovitosti nekaterih kazni.

- Med 8. in 9. razredom so razlike v oceni pogostosti določenih kazni.

- Med 8. in 9. razredom so razlike v oceni učinkovitosti določenih kazni.

- Obstaja povezanost med oceno pogostosti šolskih kazni učencev in učiteljev.

- Obstaja povezanost med oceno učinkovitosti šolskih kazni učencev in učiteljev.

- Učitelji in učenci vidijo vzrok kaznovanja v tem, da bi učenci prenehali z vedenjem, ki ni primerno.

- Učenci se po pomoč največkrat zatečejo k staršem.

- Učitelji se največkrat po pomoč obrnejo h kolegom.

- Število let delovne dobe učitelja ne vpliva na pogostost kaznovanja.

Prav tako sva celostno pogledala v delovanje in zaznavanje kaznovanja šolskih svetovalnih delavk in tako dobila kompleksnejši pogled na kaznovanje v sodobni osnovni šoli. Pri kvalitativnem delu so naju vodila raziskovalna vprašanja iz naslednjih področij:

- Delovne naloge šolskih svetovalnih delavk in identifikacija problemov.

- Zaznavanje kaznovanja v šoli s strani šolskih svetovalnih delavk.

- Oblike sodelovanja med šolskimi svetovalnimi delavkami in učitelji.

- Vloga šolskih svetovalnih delavk v procesu kaznovanja ter njihov pogled na vlogo staršev in vodstva v procesu kaznovanja.

- Mnenje šolskih svetovalnih delavk o nekaterih šolskih kaznih in njihov odnos do učencev.

- Vpliv spola učenca in ostali dejavniki, ki vplivajo na način kaznovanja in poučevanja.
- Vzroki za neprimerno vedenje učencev ter vzroki za spremembo.

- Trendi v delovanju šole in šolske svetovalne službe.

\subsection{Merski instrument in značillnosti vzorca}

Zaradi narave teme in raziskovane populacije sva za obdelavo podatkov uporabila kvalitativni in kvantitativni pristop. V okviru kvantitativnega dela raziskave sva podatke zbrala s pomočjo Vprašalnika o vzgojnih ukrepih za učence in njemu primerljivega Vprašalnika o vzgojnih ukrepih za učitelje. Vprašalnik ugotavlja pogostost uporabe določenih kazni v šolskem prostoru ter učinkovitost le-teh. Kvalitativni del raziskave sva opravila s pomočjo odprtih intervjujev s šolskimi svetovalnimi delavkami na temo kaznovanja v šoli.

Vprašalnike o vzgojnih ukrepih so izpolnili učenci 8. in 9. razreda na petih slovenskih šolah. Razdeljenih je bilo 470 Vprašalnikov za učence, 16 se jih je v nadaljnji obdelavi izkazalo za neveljavne. Učiteljem je bil razdeljen 101 Vprašalnik, 20 učiteljev Vprašalnika ni vrnilo.

Opravila sva tudi kvalitativni del raziskave, ki ga predstavljajo trije intervjuji s šolskimi svetovalnimi delavkami (pedagoginjo, socialno pedagoginjo in psihologinjo). Sodelujoče v intervjujih sva iskala na osnovnih šolah, ki so bile vključene v kvantitativno raziskavo.

Kvantitativne podatke sva zbirala $\mathrm{z}$ Vprašalnikom 0 vzgojnih ukrepih za učence in njemu primerljivim Vprašalnikom o vzgojnih ukrepih za učitelje. Vprašalnika sta sestavljena iz dveh delov. V prvem so podane različne kazni, katerim anketiranec pripiše pogostost (pri tem je ocena 1 pomenila nikoli in 5 vedno) in učinkovitost (ocena 1 je pomenila, da učinkovitosti ni, ocena 5 pa zelo veliko učinkovitost). Ta del sestavljajo različne kategorije kazni, delno po zgledu razdelitve šolskih kazni F. Strmčnika (1965). Prvi sklop se je nanašal na upravno-administrativne kazni, drugi na področje moralno obsojajočih sankcij, tretja kategorija so poravnalne kazni, sledi sklop omejitvenih kazni, peti sklop zajema kazni profaniranja učenca, nato kategorija verbalnih kazni ter sklop telesna kazen. Drugi del vprašalnika predstavljata dve vprašanji zaprtega tipa, kjer sem spraševala po vzrokih za kaznovanje ter kam se anketiranec zateče po pomoč, ko ne ve kako kaznovati oz. ko je po krivici kaznovan. 


\begin{tabular}{|l|r|r|r|r|r|r|}
\hline $\begin{array}{c}\text { Spol / } \\
\text { Razred }\end{array}$ & \multicolumn{2}{|c|}{ 8. razred } & \multicolumn{2}{|c|}{ 9. razred } & \multicolumn{2}{|c|}{$\sum$} \\
\hline & $\mathrm{f}$ & $\%$ & $\mathrm{f}$ & $\%$ & $\mathrm{f}$ & $\%$ \\
\hline Učenka & 122 & 49 & 89 & 43,4 & 211 & 46,5 \\
\hline Učenec & 127 & 51 & 116 & 56,6 & 243 & 53,5 \\
\hline$\sum$ & 249 & 100 & 205 & 100 & 454 & 100 \\
\hline
\end{tabular}

Tabela 1: Struktura vzorca učencev po spolu in razredih

\begin{tabular}{|l|c|c|}
\hline Spol & $\mathbf{f}$ & $\%$ \\
\hline Učiteljica & 71 & 89,9 \\
\hline Učitelj & 8 & 10,1 \\
\hline$\Sigma$ & 79 & 100 \\
\hline
\end{tabular}

Tabela 2: Struktura vzorca učiteljev po spolu

Kvalitativni del raziskave je zajel 3 predstavnice šolske svetovalne službe (pedagoginjo, socialno pedagoginjo in psihologinjo).

Za statistično obdelavo podatkov sta bila uporabljena računalniška programa Excel in SPSS za Windows XP. Podatki, dobljeni z Vprašalnikoma o vzgojnih ukrepih so bili oštevilčeni. Veljavnost hipotez sva ugotavljala s $\chi^{2}$ preizkusom ter primerjavo aritmetičnih sredin vzorca učiteljev in učencev. Za ugotavljanje povezanosti ocen sva uporabljala Pearsonov korelacijski koeficient.

\section{Rezultati raziskave}

Hipoteze sva zaradi preglednosti preverjala sproti v sklopu kategorij kazni, ki sva jih deloma oblikovala po zgledu Strmčnika (1965).

\subsection{Kategorija upravno - administrativnih kazni}

V to kategorijo sodijo naslednje kazni: vpis v dnevnik, ukor, premestitev v drug razred ter prešolanje.

V kategoriji upravno-administrativne kazni so razlike med učenkami in učenci. Nekoliko pogostejša je uporaba vpisa v dnevnik za učenke. $\chi^{2}$ - test potrjuje, da med spolom učenca in oceno pogostosti te kazni obstaja statistično pomembna povezanost $\left(\chi^{2}=12,605\right.$; s.p. $\left.=4 ; \mathrm{P}\left(\mathrm{H}_{0}\right)=0,013\right)$.
Povezanost se kaže predvsem v večjem deležu učenk, ki vpis v dnevnik doživljajo kot pogosto obliko kaznovanja. $\chi^{2}$ - test potrjuje, da med spolom učenca in pogostostjo premestitve $\mathrm{v}$ drug oddelek obstaja statistično pomembna povezanost $\left(\chi^{2}=9,930\right.$; s.p. $\left.=4 ; \mathrm{P}\left(\mathrm{H}_{0}\right)=0,042\right)$. Povezanost se kaže predvsem v večjem deležu učencev, ki kazen zaznavajo kot redko. $\chi^{2}$ - test potrjuje, da med spolom učenca in pogostostjo kazni prešolanja obstaja statistično pomembna povezanost $\left(\chi^{2}=11,496\right.$; s.p. $\left.=4 ; \mathrm{P}\left(\mathrm{H}_{0}\right)=0,022\right)$. Opazimo, da učenci pogosteje zaznavajo prešolanje.

Od kazni, ki sodi v omenjeno kategorijo, le ocena vpis $\mathrm{v}$ dnevnik po mnenju učencev po pogostosti presega učinkovitost. Učenke in učenci so opredelili pogostost pojavljanja teh kazni kot majhno $(1,96)$. Učinkovitost je v povprečju po njihovem večja, čeprav jo opredeljuje kot majhno $(2,35)$.

V kategoriji upravno-administrativnih kazni so razlike med učenci 8. in 9. razreda. Vpis v dnevnik pogosteje občutijo učenci 9 . razredov. $\chi^{2}-$ test potrjuje, da med razredom učenca in oceno pogostosti te kazni obstaja statistično pomembna povezanost $\left(\chi^{2}=11,460\right.$; s.p. $=4$; $\mathrm{P}\left(\mathrm{H}_{0}\right)=0,022$ ). Povezanost se kaže v večjem deležu devetošolcev, ki kazen sprejemajo kot nekaj običajnega. Ukor ocenjujejo učenci 8. razreda kot bolj učinkovit. $\chi^{2}$ - test potrjuje, da med razredom učenca in učinkovitostjo te kazni obstaja statistično pomembna povezanost $\left(\chi^{2}=18,558 ;\right.$ s.p. $\left.=4 ; \mathrm{P}\left(\mathrm{H}_{0}\right)=0,001\right)$. Povezanost se kaže v večjem deležu osmošolcev, ki menijo, da je ukor zelo učinkovita kazen. Premestitev v drug oddelek pogosteje zaznavajo učenci 9 . razreda. $\chi^{2}$ - test potrjuje, da med razredom učenca in pogostostjo te kazni obstaja statistično pomembna povezanost $\left(\chi^{2}=13,196 ;\right.$ s.p. $\left.=4 ; \mathrm{P}\left(\mathrm{H}_{0}\right)=0,010\right)$. Opazimo, da večjo pogostost premestitve $\mathrm{v}$ drug oddelek zaznavajo učenci 9. razreda, vendar tudi ti to kazen zaznavajo redko.

Učitelji upravno-administrativnih kazni sploh ne zaznavajo oz. jih vidijo kot redke. Vsem upravno-administrativnim kaznim so dali večjo oceno učinkovitosti v primerjavi z oceno pogostosti. Učitelji menijo, da je učinkovitost upravno-administrativnih kazni majhna.

Učenci vse upravno-administrativne kazni zaznavajo pogosteje kot učitelji ocenjujejo, da se jih poslužujejo. Učenci le kazen vpisa v dnevnik vidijo kot manj učinkovito $\mathrm{v}$ primerjavi z ocenami učiteljev. 


\subsection{Kategorija moralno obsojajočih kazni}

V to kategorijo sodijo naslednje kazni z vprašalnika: zagovor pri razredniku, pogovor pri ravnatelju ali šolski svetovalni službi, ignoriranje, obvestitev staršev.

V kategoriji moralno obsojajočih kazni ni razlik med učenkami in učenci glede pogostosti teh kazni. Učenke in učenci so opredelili pogostost pojavljanja teh kazni kot majhno do srednjo. V tej kategoriji so razlike med učenkami in učenci glede učinkovitosti kazni le pri kazni obvestitev staršev, za katero fantje menijo, da je bolj učinkovita. $\chi^{2}$ test potrjuje, da med spolom učenca in oceno učinkovitosti kazni obvestitev staršev obstaja statistično pomembna povezanost $\left(\chi^{2}=12,100 ;\right.$ s.p. $\left.=4 ; \mathrm{P}\left(\mathrm{H}_{0}\right)=0,017\right)$. Učencem se zdi obveščanje staršev bolj učinkovita kazen v primerjavi z mnenjem učenk, saj večji delež učencev opredeljuje učinkovitost kot veliko. Učinkovitost je v kategoriji v povprečju manjša od pogostosti, učinkovitost je majhna. Kazni zagovor pri razredniku, ignoriranje in obveščanje staršev po pogostosti presegajo učinkovitost.

V kategoriji moralno obsojajočih kazni so razlike med učenci 8. in 9. razreda glede pogostosti teh kazni. Učenci 9. razreda prav vse kazni, razen obvestitve staršev, doživljajo pogosteje kot učenci 8 . razreda. $\chi^{2}$ - test potrjuje, da med razredom učenca in pogostostjo kazni zagovora pri razredniku obstaja statistično pomembna povezanost $\left(\chi^{2}=14,340 ;\right.$ s.p. $\left.=4 ; \mathrm{P}\left(\mathrm{H}_{0}\right)=0,006\right)$. Učenci 9. razreda pogosteje zaznajo zagovor pri razredniku, saj ga večji delež učencev smatra za običajno ali pogosto kazen. $\chi^{2}$ - test potrjuje, da med razredom učenca in pogostostjo kazni pogovora pri ravnatelju ali šolski svetovalni službi, obstaja statistično pomembna povezanost $\left(\chi^{2}=18,439\right.$; s.p. $=4$; $\left.\mathrm{P}\left(\mathrm{H}_{0}\right)=0,001\right)$. Povezanost se kaže v večjem deležu devetošolcev, ki to kazen sprejemajo kot nekaj običajnega oziroma kot pogosto. $\chi^{2}$ - test potrjuje, da med razredom učenca in oceno pogostosti ignoriranja obstaja statistično pomembna povezanost $\left(\chi^{2}=17,053\right.$; s.p. $\left.=4 ; \mathrm{P}\left(\mathrm{H}_{0}\right)=0,002\right)$. Povezanost se kaže v večjem deležu devetošolcev, ki kazen zaznavajo kot pogosto. $\chi^{2}$ - test potrjuje, da med razredom učenca in oceno pogostosti kazni obvestitev staršev obstaja statistično pomembna povezanost $\left(\chi^{2}=16,022\right.$; s.p. $=4$; $\left.\mathrm{P}\left(\mathrm{H}_{0}\right)=0,003\right)$. Učenci 8. razreda kažejo malo večje zaznavanje pogostosti obveščanja staršev kot devetošolci. Glede ocene učinkovitosti med 8. in 9. razredom ni razlik.
Učitelji moralno obsojajoče kazni v splošnem zaznavajo kot redko pojavljajoče se kazni. Vsem moralno obsojajočim kaznim so dali večjo oceno učinkovitosti v primerjavi z oceno pogostosti. Mnenje učiteljev o učinkovitosti se nagiba k srednji učinkovitosti.

Učenci prav vse moralno obsojajoče kazni zaznavajo pogosteje, kot ocenjujejo učitelji, da jih uporabljajo. Pri učinkovitosti moralno obsojajočih kazni pa je ravno obratno: učitelji v vseh kaznih vidijo večjo učinkovitost $\mathrm{v}$ primerjavi z učenci.

\subsection{Kategorija poravnalnih kazni}

V to kategorijo sodijo naslednje kazni z vprašalnika: denarna kazen, popravilo šolske lastnine, zamenjava poškodovanega predmeta.

V kategoriji poravnalnih kazni ni razlik med učenkami in učenci glede pogostosti teh kazni. Učenke in učenci so opredelili pogostost pojavljanja teh kazni kot majhno. Učinkovitost je v povprečju večja od pogostosti, ki pa je še vedno majhna.

V kategoriji poravnalnih kazni so razlike med učenci 8. in 9. razreda glede pogostosti zaznavanja teh kazni. Učenci 9. razreda pogosteje občutijo denarno kazen. $\chi^{2}$ - test potrjuje, da med razredom učenca in oceno pogostosti denarne kazni obstaja statistično pomembna povezanost $\left(\chi^{2}=9,675 ;\right.$ s.p. $\left.=4 ; \mathrm{P}\left(\mathrm{H}_{0}\right)=0,046\right)$. Povezanost se kaže v večjem deležu devetošolcev, ki občutijo denarno kazen kot pogosto obliko kaznovanje. $\chi^{2}$ - test potrjuje, da med razredom učenca in oceno pogostosti kazni zamenjave poškodovanega predmeta obstaja statistično pomembna povezanost $\left(\chi^{2}=11,139\right.$; s.p. $\left.=4 ; \mathrm{P}\left(\mathrm{H}_{0}\right)=0,025\right)$. Povezanost se kaže predvsem v večjem deležu devetošolcev, ki kazen sprejemajo kot nekaj običajnega.

Učitelji poravnalne kazni v splošnem zaznavajo kot redko pojavljajoče se kazni. Vsem poravnalnim kaznim so učitelji dali večjo oceno učinkovitosti v primerjavi z oceno pogostosti. Učitelji menijo da so poravnalne kazni srednje učinkovite.

Učenci le denarno nadomestilo za poškodovano šolsko lastnino zaznajo kot pogostejšo v primerjavi z oceno učiteljev. Učitelji prav vsem poravnalnim kaznim pripisujejo večjo učinkovitost v primerjavi z ocenami učencev.। 


\subsection{Kategorija omejitvenih kazni}

V to kategorijo sodijo naslednje kazni z vprašalnika: dodatne (domače) naloge, pripor po pouku, prepoved udeležbe na šolskem izletu.

V kategoriji omejitvenih kazni ni razlik med učenkami in učenci glede pogostosti in učinkovitosti teh kazni. Učenke in učenci so ocenili, da se kazni redko ali nikoli ne pojavljajo. Učinkovitost je v povprečju večja od pogostosti, a kljub vsemu še vedno majhna.

V kategoriji omejitvenih kazni so razlike med osmošolci in devetošolci glede pogostosti in učinkovitosti teh kazni. Učenci 9. razreda pogosteje zaznavajo prepoved udeležbe na šolskem izletu. $\chi^{2}$ - test potrjuje, da med razredom učenca in oceno pogostosti kazni prepovedi udeležbe na šolskem izletu obstaja statistično pomembna povezanost $\left(\chi^{2}=31,470\right.$; s.p. $\left.=4 ; \mathrm{P}\left(\mathrm{H}_{0}\right)=0,000\right)$. Ocene o pogostosti prepovedi udeležbe na šolskem izletu, kot so jih podali osmošolci in devetošolci, se med seboj zelo razlikujejo. Učenci 9. razreda pogosteje zaznavajo oziroma občutijo to kazen, saj jih večji delež sprejema to kazen kot nekaj običajnega in jo tudi ocenjujejo kot bolj učinkovito. $\chi^{2}$ - test potrjuje, da med razredom učenca in oceno učinkovitosti te kazni obstaja statistično pomembna povezanost $\left(\chi^{2}=16,028\right.$; s.p. $\left.=4 ; \mathrm{P}\left(\mathrm{H}_{0}\right)=0,003\right)$. Učenci 9. razreda ocenjujejo prepoved udeležbe na šolskem izletu kot bolj učinkovito kazen v primerjavi z učenci 8 . razreda.

Učitelji pravijo, da se omejitvenih kazni nikoli ne poslužujejo, njihovo učinkovitost označujejo kot majhno. Učitelji so vsem omejitvenim kaznim dali večjo oceno za učinkovitost $\mathrm{v}$ primerjavi s pogostostjo.

Učenci so le priporu po pouku pripisali manjšo učinkovitost, kot so jo ocenili učitelji. Učitelji za prav vse omejitvene kazni menijo, da se pojavljajo manj pogosto kot le-to zaznavajo učenci.

\subsection{Kategorija osramotitvenih kazni}

V to kategorijo sodijo naslednje kazni z vprašalnika: stanje v klopi, presedanje v drugo klop, pošiljanje iz razreda, kazensko spraševanje za oceno.

V kategoriji osramotitvenih kazni so razlike med učenkami in učenci glede pogostosti pri kazni stanje $\mathrm{v}$ klopi, pri učinkovitosti teh kazni ni razlik. Učenke in učenci so ocenili, da se kazni redko do občasno pojavljajo. $\chi^{2}$ - test potrjuje, da med spolom učenca in pogostostjo kazni stanje v klopi obstaja statistično pomembna povezanost $\left(\chi^{2}=13,046\right.$; s.p. $\left.=4 ; \mathrm{P}\left(\mathrm{H}_{0}\right)=0,011\right)$. Učenci so pogosteje deležni te kazni, povezanost se torej kaže $\mathrm{v}$ večjem deležu učencev, ki kazen opredeljuje kot redko in običajno. Učinkovitost je v povprečju manjša od pogostosti pojavljanja kazni iz teh kategorij, ocenili so jih kot malo učinkovite.

V kategoriji osramotitvenih kazni ni razlik med osmošolci in devetošolci.

Učitelji ocenjujejo, da osramotitvenih kazni nikoli ne uporabljajo oziroma se v oceni nagibajo k redki uporabi. Učitelji so vsem osramotitvenim kaznim dali večjo oceno za učinkovitost v primerjavi s pogostostjo. Kazni iz te kategorije se jim sicer zdijo malo učinkovite.

Učenci so prav vsem osramotitvenim kaznim pripisali večjo pogostost kot učitelji. Učenci so kazni stati v klopi in kazenskemu spraševanju za oceno pripisali večjo učinkovitost kot so jo opredelili učitelji.

\subsection{Kategorija verbalnih kazni}

V to kategorijo sodijo naslednje kazni z vprašalnika: kričanje, zmerjanje, dajanje nadimkov ali zbadljivk.

V kategoriji verbalnih kazni so razlike med učenkami in učenci pri kazni dajanje nadimkov ali zbadljivk. $\chi^{2}$ - test potrjuje, da med spolom učenca in pogostostjo te kazni obstaja statistično pomembna povezanost $\left(\chi^{2}\right.$ $=9,755$; s.p. $\left.=4 ; \mathrm{P}\left(\mathrm{H}_{0}\right)=0,045\right)$. Povezanost se kaže v večjem deležu fantov, ki dajanje nadimkov ali zbadljivk zaznavajo kot nekaj običajnega oz. kot pogosto ali kazen, ki se vedno pojavlja. Učenke in učenci so ocenili, da so verbalne kazni redke do običajne. Učinkovitost verbalnih kazni je v povprečju manjša od pogostosti in sicer menijo učenke in učenci, da imajo kazni iz te kategorije majhno učinkovitost.

V kategoriji verbalnih kazni so razlike med osmošolci in devetošolci pri oceni pogostosti pri kazni dajanje nadimkov ali zbadljivk. $\chi^{2}$ - test potrjuje, da med razredom učenca in oceno pogostosti te kazni obstaja statistično pomembna povezanost $\left(\chi^{2}=11,412\right.$; s.p. $\left.=4 ; \mathrm{P}\left(\mathrm{H}_{0}\right)=0,022\right)$. Povezanost se kaže v večjem deležu devetošolcev, ki kazen zaznavajo kot nekaj običajnega. 
Učitelji ocenjujejo, da verbalnih kazni nikoli ne uporabljajo oziroma se v oceni nagibajo k redki uporabi. Učitelji so vsem verbalnim kaznim dali večjo oceno za učinkovitost v primerjavi s pogostostjo. Učitelji ocenjujejo kazni iz te kategorije kot neučinkovite do malo učinkovite.

Učenci so vsem verbalnim kaznim pripisali večjo pogostost kot učitelji. Učitelji so le kričanju pripisali malo večjo učinkovitost $\mathrm{v}$ primerjavi $\mathrm{z}$ oceno učencev.

\subsection{Kategorija telesne kazni}

V to kategorijo sodi kazen, ko učitelj fizično obračuna $\mathrm{z}$ učencem, ko ga udari z roko ali predmetom. Telesna kazen je v Pravilniku o pravicah in dolžnostih učencev (1996) izrecno opredeljena kot prepovedana sankcija.

V kategoriji telesna kazen so razlike med učenkami in učenci tako glede ocene pogostosti kot tudi ocene učinkovitosti uporabe udarcev. Fantje pogosteje zaznavajo to kazen, prav tako ji pripisujejo tudi večjo učinkovitost. $\chi^{2}$ - test potrjuje, da med spolom učenca in pogo- $\left(\chi^{2}=26,985 ;\right.$ s.p. $\left.=4 ; \mathrm{P}\left(\mathrm{H}_{0}\right)=0,000\right)$. Učenke in učenci zelo različno občutijo pogostost pojavljanja fizične kazni. Povezanost se kaže predvsem v večjem deležu fantov, ki zaznavajo telesno kazen kot nekaj običajnega oz. kot pogosto ali kot kazen, ki se jo učitelj vedno poslužuje. Učenke in učenci so ocenili, da se fizična kazen v povprečju v šoli ne uporablja oz. je pogostost pojavljanja majhna. $\chi^{2}$ - test potrjuje, da med spolom učenca in učinkovitostjo telesne kazni obstaja statistično pomembna povezanost $\left(\chi^{2}=15,722 ;\right.$ s.p. $\left.=4 ; \mathrm{P}\left(\mathrm{H}_{0}\right)=0,003\right)$. Učenke in učenci zelo različno ocenjujejo učinkovitost udarcev. Učenci vidijo $\mathrm{v}$ telesni kazni večjo učinkovitost kot učenke. Učinkovitost udarcev je po mnenju učencev in učenk večja od pogostosti in se nagiba k majhni učinkovitosti.

V kategoriji telesna kazen je razlika med osmošolci in devetošolci v zaznavanju pogostosti te kazni. $\chi^{2}$ - test potrjuje, da med razredom učenca in oceno pogostosti te kazni obstaja statistično pomembna povezanost $\left(\chi^{2}\right.$ $=12,593 ;$ s.p. $\left.=4 ; \mathrm{P}\left(\mathrm{H}_{0}\right)=0,013\right)$. Učenci 9. razreda pogosteje kot učenci 8. razreda občutijo oz. zaznavajo telesno kazen.




Učitelji ocenjujejo, da se udarcev nikoli ne poslužujejo. Pripisujejo jim večjo učinkovitost v primerjavi s pogostostjo, menijo, da fizična kazen ni učinkovita oz. da je malo učinkovita.

Učenci so telesni kazni pripisali večjo pogostost in večjo učinkovitost kot učitelji.

\subsection{Povezanost ocen učencev in učiteljev}

Ocene učencev in učiteljev o pogostosti uporabe kazni so povezane. Pearsonov korelacijski koeficient znaša 0,65 , kar pomeni zmerno pozitivno korelacijo.

Učenci in učitelji kljub različnemu zaznavanju pogostosti določenih kazni v splošnem podobno zaznavajo pogostost kaznovanja $\mathrm{v}$ šolah, se pravi, da so ocene $\mathrm{z}$ obeh strani dokaj realne.

Ocene učencev in učiteljev o učinkovitosti kazni so povezane. Pearsonov korelacijski koeficient znaša 0,76, kar pomeni visoko pozitivno korelacijo.

Torej učenci in učitelji kljub različnemu zaznavanju učinkovitosti določenih kazni v splošnem podobno ocenjujejo učinkovitost kaznovanja v šolah, se pravi, da so ocene z obeh strani realne. Strmčnik (1965) pravi, da so podatki o ujemanju ocene učinkovitosti, ki so jo podali učenci in tiste, ki so jo podali učitelji pomembni za šolsko kazensko prakso. Čim bolj se približajo nazori učiteljstva o učinkovitosti kazni realnemu doživljanju teh pri učencih, tem uspešnejše bo kaznovanje.

\subsection{Vzroki za kaznovanje}

Tako učenci kot učitelji vidijo glavni vzrok kaznovanja $\mathrm{v}$ šoli predvsem $\mathrm{v}$ tem, da učenci prenehajo $\mathrm{z}$ neprimernim vedenjem. Zaskrbljujoč je dokaj visok odstotek $(11,7 \%)$ tistih učencev, ki menijo, da jih učitelj kaznuje, ker jih "ima na piki" ter tistih učencev ( $4,7 \%$ ), ki ne vedo, zakaj so kaznovani.

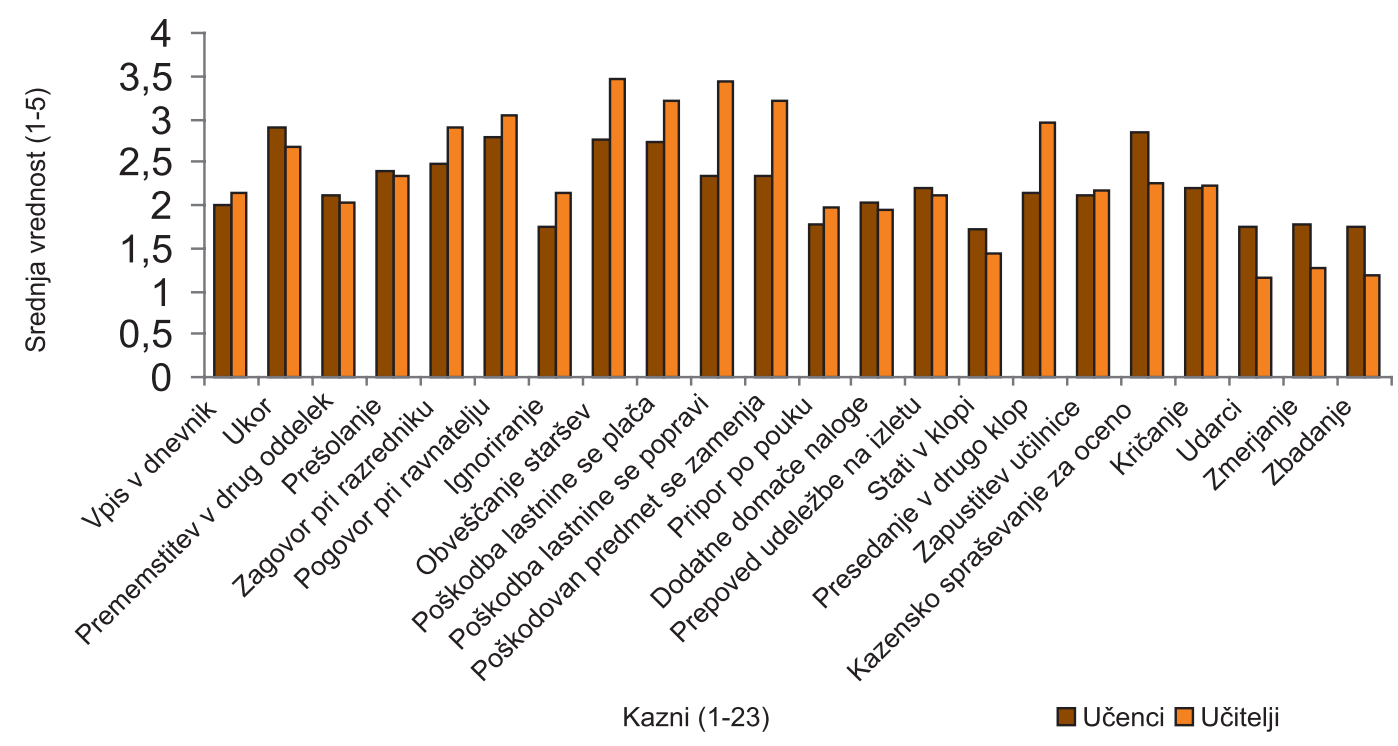

Graf 2:

Primerjalni graf srednjih vrednosti ocen učencev in učiteljev 0 učinkovitosti posameznih kazni 


\begin{tabular}{|ll|r|r|r|r|}
\hline & & Frequency & Percent & Valid Percent & $\begin{array}{c}\text { Cumulative } \\
\text { Percent }\end{array}$ \\
\hline Valid & da spoznam, da neposlušnosti sledi kazen & 23 & 4,9 & 5,1 & 5,1 \\
& da preneham z vedenjem, ki ni primerno & 325 & 68,9 & 72,2 & 77,3 \\
& kazen je opomin ostalim učencem, da ne & 25 & 5,3 & 5,6 & 82,9 \\
& bi poskušali kaj podobnega & & & \\
& učitelj me ne mara, me ima na "piki" & 55 & 11,7 & 12,2 & 95,1 \\
& ne vem & 22 & 4,7 & 4,9 & 100,0 \\
& Total & 450 & 95,3 & 100,0 & \\
Missing & System & 22 & 4,7 & & \\
Total & & 472 & 100,0 & & \\
\hline
\end{tabular}

Tabela 3: Vzroki za kaznovanje, kot jih vidijo učenci

\begin{tabular}{|c|c|c|c|c|c|}
\hline & & Frequency & Percent & $\begin{array}{c}\text { Valid } \\
\text { Percent }\end{array}$ & $\begin{array}{l}\text { Cumula- } \\
\text { tive } \\
\text { Percent }\end{array}$ \\
\hline \multirow[t]{4}{*}{ Valid } & 1 & 4 & 4,7 & 5,0 & 5,0 \\
\hline & 2 & 75 & 88,2 & 93,8 & 98,8 \\
\hline & 3 & 1 & 1,2 & 1,3 & 100,0 \\
\hline & Total & 80 & 94,1 & 100,0 & \\
\hline Missing & System & 5 & 5,9 & & \\
\hline Total & & 85 & 100,0 & & \\
\hline
\end{tabular}

Tabela 4: Vzroki za kaznovanje, kot jih vidijo učitelji

$$
\begin{aligned}
& \text { Legenda: } \\
& \text { 1- Da spozna, da neposlušnosti sledi kazen. } \\
& 2 \text { - Da preneha z vedenjem, ki ni primerno. } \\
& 3 \text { - Kazen je opomin ostalim učencem, da ne } \\
& \text { bi poskušali kaj podobnega. }
\end{aligned}
$$

Učitelji v veliki večini ( $88,2 \%)$ pravijo, da se poslužujejo kaznovanja zato, da učenci prenehajo z vedenjem, ki ni primerno. Le 4 učitelji kaznujejo zato, da učenci spoznajo, da neposlušnosti sledi kazen, 1 učitelj vidi v kaznovanju učenca opomin ostalim učencem, da ne bi poskušali kaj podobnega. 5 učiteljev ni želelo odgovoriti, kje so vzroki za njihovo kaznovanje.

Iz tega lahko sklepamo, da tako učenci kot učitelji vidijo glavni vzrok kaznovanja $\mathrm{v}$ šoli predvsem $\mathrm{v}$ tem, $\mathrm{da}$ učenci prenehajo z neprimernim vedenjem. Učitelji se kaznovanja poslužujejo predvsem za vzpostavljanje discipline in ne toliko kot vzgojno sredstvo, ki bi dolgoročno vplivalo na vedenje učenca. Učitelji višjih razredov vidijo svojo dolžnost predvsem v poučevanju in za to potrebujejo pozornost učencev, da si jo pridobijo jih občasno kaznujejo. Vzgoja je v očeh učiteljev predvsem dolžnost staršev.

\subsection{Kam po pomoč?}

Izkazalo se je, da spol pomembno vpliva na to, kam se učenec/ka zateče po pomoč, ko je krivično kaznovan/a. Tako se dekleta najpogosteje obrnejo po pomoč k staršem. Fantje najpogosteje iščejo pomoč pri prijateljih, sledijo pa jim starši.

Preseneča majhen odstotek učenk $(6,8 \%)$ in učencev $(4,1 \%)$, ki iščejo pomoč pri šolski svetovalni službi, ki ponavadi velja za nek nevtralen člen šolskega sistema. Predvidevam, da so učenci prevečkrat k svetovalnim delavcem napoteni zaradi prekrškov, ki jih storijo, in zato ne želijo zbujati zanimanja takrat, ko se jim zgodi krivica. Očitno učenke in učenci vse prevečkrat občutijo pristranskost 


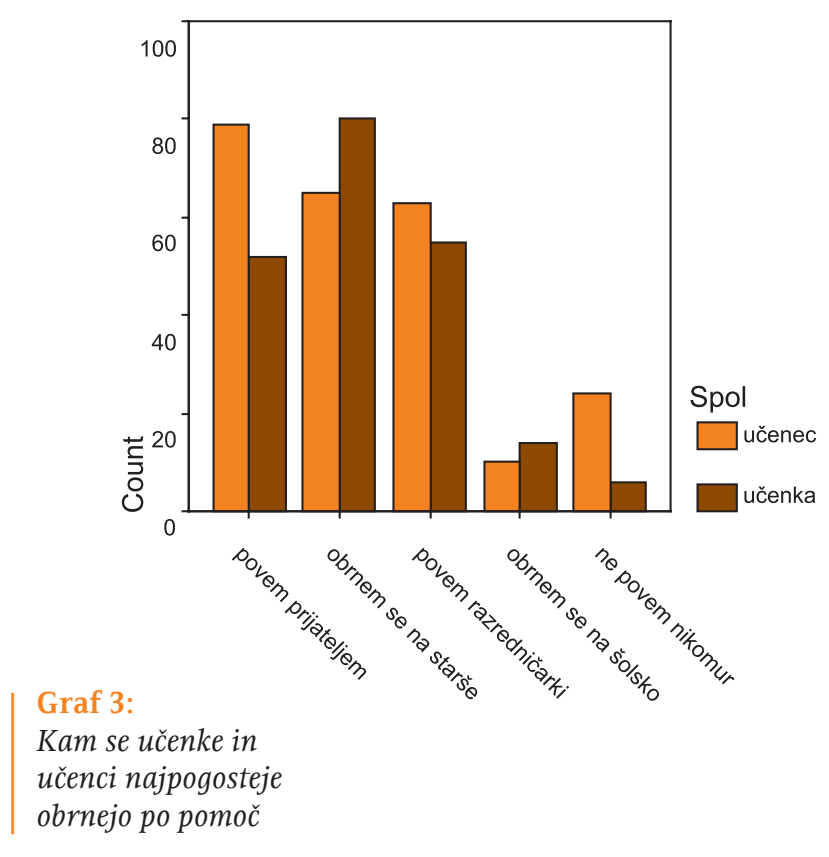

svetovalne službe, ki jih ne posluša, temveč bolj verjame učitelju. Pri tem se izpostavlja tudi vprašanje strokovnega ravnanja in same usposobljenosti svetovalne službe za postopanje $\mathrm{v}$ tovrstnih primerih.
Fantje so se izkazali v primeru krivičnega kaznovanja za precej bolj vase zaprte. Se pravi, da tisti, ki ne morejo o krivici povedati prijateljem, staršem ali razredničarki raje v večjem deležu raje molčijo, kot da bi se obrnili na šolsko svetovalno službo. Pri dekletih je molk najmanj pogosta izbira.

$\chi^{2}$ - test potrjuje, da med spolom učenca in kam se učenec zateče po pomoč obstaja statistično pomembna povezanost $\left(\chi^{2}=16,641\right.$; s.p. $\left.=4 ; \mathrm{P}\left(\mathrm{H}_{0}\right)=0,002\right)$. Tako ugotavljava, da se učenke dejansko najpogosteje zatečejo po pomoč k staršem.

Zanimalo naju je tudi, kam se po pomoč zatečejo učenke in učenci, ki jih je učitelj že kdaj udaril in s tem uporabil z zakonom prepovedano kazen, za katero vsi, tudi učenci vedo, da ne bi smela imeti mesta v šoli. Odgovori teh učencev so posebni in se razlikujejo od ostalih. Izkazalo se je, da je kar 69 učencev in 21 učenk učitelj že kdaj udaril (redko, običajno...). Učenci se v takih primerih najpogosteje zatečejo k prijateljem, podobno kot pri ostalih kaznih, sledi razrednik, na tretjem mestu pa so starši. 7 učencev ni o tem, da jih je učitelj udaril, povedalo nikomur, 6 pa se jih je obrnilo na šolsko svetovalno službo. Učenke se v enakem deležu zatečejo k prijateljicam in razredničarki, na tretjem mestu so starši. 1 učenka ni o tej kazni povedala nikomur in prav nobena od učenk se ni obrnila na šolsko

\begin{tabular}{|ll|l|r|r|r|}
\hline & & & \multicolumn{2}{|c|}{ Spol } & \multirow{2}{*}{ Total } \\
\cline { 4 - 5 } & & učenec & Učenka & \\
\hline Kam se najpogosteje \\
zatečeš po pomoč, če \\
te učitelj po krivici & povem prijateljem & Count & 30 & 7 & 37 \\
kaznuje & \multirow{2}{*}{ obrnem se na starše } & Expected Count & 28,4 & 8,6 & 37,0 \\
& & Count & 11 & 6 & 17 \\
& povem razredničarki & Count & 13,0 & 4,0 & 17,0 \\
& & 15 & 7 & 22 \\
& obrnem se na šolsko & Count & 16,9 & 5,1 & 22,0 \\
& svetovalno službo & Expected Count & 4,6 & 0 & 6 \\
& ne povem nikomur & Count & 7 & 1,4 & 6,0 \\
& & Expected Count & 6,1 & 1,9 & 8 \\
Total & Count & 69 & 21 & 90 \\
& & Expected Count & 69,0 & 21,0 & 90,0 \\
\hline
\end{tabular}

Tabela 5:

Kam se zatečejo po pomoč učenci, ki so bili telesno kaznovani 
svetovalno službo. Glede na to, da je telesna kazen drastičen in prepovedan ukrep je po svoje presenetljivo, da učenke o tem ne spregovorijo s starši. Vendar to kaže na sodoben trend odtujenih staršev in otrok, na način življenja. Zdi se, da so ti otroci kot skupina nekaj posebnega in v nadaljnjih raziskavah bi bilo vsekakor potrebno usmeriti pozornost na njihovo specifičnost, posebnost, ki jih determinira, da postanejo žrtve telesne kazni.

Učitelji se v dilemi, kako kaznovati in ali sploh kaznovati najpogosteje $(30,6 \%)$ po pomoč zatečejo $\mathrm{h}$ kolegom. $24,7 \%$ se o tem pogovori z razrednikom otroka oz. razreda, s katerim/v katerem ima težave. $21,2 \%$ učiteljev se obrne na šolsko svetovalno službo. 9 učiteljev samih ureja probleme, 5 pa se jih obrne na starše otrok/a. 6 učiteljev ni želelo odgovoriti na vprašanje, kam se zatečejo po pomoč.

\subsection{Vpliv delovne dobe učitelja na povprečno oceno pogostosti uporabe kazni}

Zanimalo naju je, ali obstaja korelacija med leti službovanja in dela z otroki ter povprečno oceno pogostosti uporabe kazni, kot so jo podali učitelji.

\begin{tabular}{|c|c|c|c|}
\hline & & POVPRSV & Leta sluzbe \\
\hline \multirow{2}{*}{$\begin{array}{l}\text { Povprečna } \\
\text { ocena pogostosti } \\
\text { uporabe kazni }\end{array}$} & $\begin{array}{l}\text { Pearson } \\
\text { Correlation }\end{array}$ & 1 &,$- 277\left(^{*}\right)$ \\
\hline & Sig. (2-tailed) & & ,027 \\
\hline \multirow{4}{*}{ Leta sluzbe } & $\mathrm{N}$ & 67 & 64 \\
\hline & $\begin{array}{l}\text { Pearson } \\
\text { Correlation }\end{array}$ &,$- 277\left(^{*}\right)$ & 1 \\
\hline & Sig. (2-tailed) & ,027 & . \\
\hline & $\mathrm{N}$ & 64 & 77 \\
\hline
\end{tabular}

Tabela 6: Povezanost delovne dobe učiteljev s pogostostjo kaznovanja

${ }^{*}$ Correlation is significant at the 0.05 level (2-tailed).

Korelacija kaže, da se s povečanjem let službe, pogostost kazni nekoliko zniža (nizka negativna korelacija). Iz tega lahko sklepam, da učitelji, ki dlje poučujejo tudi nekoliko manj kaznujejo. Učitelji z več delovnih let imajo za sabo več izkušenj in so verjetno tudi že večkrat naleteli na probleme in dileme v zvezi s kaznovanjem. Verjetno izkušnje učitelje poučijo, da je kaznovanje, ki ni vzgojno, namensko in osmišljeno, neučinkovito in se ga zato precej manj poslužujejo.

\subsection{Opažanja svetovalnih delavk}

Šolski svetovalni delavci opravljajo različne naloge in se posvečajo področjem, ki jim jih dodeli vodstvo in za katerega so še posebej, glede na poklicno usmerjenost, specializirani in zato bolj kompetentni za razreševanje tovrstne problematike. Delovne naloge, ki zadevajo sodelovanje $\mathrm{z}$ učenci, učitelji in starši pripomorejo k zaznavanju in opredelitvi problemov, ki nastajajo v odnosu med učenci in učitelji. Resman (1996) pravi, da morajo 
biti svetovalni službi na šoli izhodišče pri delu razvojne potrebe in problemi učencev, potrebe učiteljev, vodstev šol in staršev.

Iz intervjujev in obdelavo le-teh sva izluščila nekatera opažanja svetovalnih delavk s področja kaznovanja, ki so jim skupna:

Učitelji pošiljajo otroke iz učilnice.

Šolska svetovalna služba kot eden od potencialnih izvrševalcev kaznovanja (v primeru, da gre za kazen, ko učitelj pošlje učenca na pogovor k šolski svetovalni službi) ter kot tretja oseba, ki naj bi vedela za konflikte med učenci in učitelji ter zaznavala nepravilnosti, dejansko zazna le nekatere oblike kaznovanja.

Tako pedagoginja, socialna pedagoginja kot tudi psihologinja povedo, da učitelji uporabljajo kazen pošiljanja učencev iz učilnice. Na eni od šol je kazen dvojna, saj učitelji učencu pišejo obenem neopravičene ure. Pošiljanje iz razreda je edina kazen, ki jo prav vse svetovalne delavke omenijo kot kaznovalno prakso učiteljev.

Učitelji in šolska svetovalna služba sodelujejo v težjih situacijah.

Odnos med šolskimi svetovalnimi delavkami in učitelji pomembno vpliva na načine in pogostnost sodelovanja med njimi. V kolikor so odnosi med njimi dobri in se učitelji ne čutijo ogrožene, je tudi sodelovanje lahko uspešnejše. Primeren odnos je predpogoj za funkcionalno sodelovanje učiteljev in šolskih svetovalnih delavk, kar pripomore tudi k zgodnjemu zaznavanju učenčevih stisk ter $\mathrm{h}$ konstruktivnemu reševanju in odpravljanju le-teh.

Eden od pogojev za uspešno opravljanje nalog s področja šolske kulture, vzgoje, klime in reda je sočasno razvojno-analitično delo svetovalnega delavca in sicer tako, da preučuje značilnosti vzgojnega ravnanja učiteljev in šole ter posledic vzgojnega ukrepanja (Svetovalna služba v osnovni šoli, 1998). Vpliv torej sega tudi v obratni smeri, saj preučevanje zahteva sodelovanje, to pa omogoča večji pregled nad kaznovanjem. Pedagoginja, socialna pedagoginja in psihologinja so si edine v izjavi, da je oblika sodelovanja med njimi in učitelji predvsem timsko sodelovanje v težjih situacijah. Slednje je izredno pomembno za kvaliteto reševanja problema. "Teamsko delo bogati vse, svetovalne delavce in druge, ki sodelujejo v teamu; ob teamskem delu se učimo drug od drugega; teamsko delo omogoča izmenjavo informacij; teamsko delo temelji na načelu kolegialnosti" (Resman, 1999b, s. 70).

Svetovalne delavke so pa ob preobilici administrativnega dela, učne pomoči ipd. tako obremenjene, da težko najdejo čas za prisostvovanje dela učiteljev v razredu in tako preventivno delovati še preden nastanejo težje situacije. Zdi se, da učitelji ne kažejo posebnega interesa za tovrstno preventivno pomoč svetovalne službe, razen, če je že nastal problem.

Učitelji predmetne stopnje kažejo manjšo pripravljenost za sodelovanje s šolsko svetovalno službo.

"Otrokovega šolskega življenja ni mogoče razumeti samo kot njegovo intelektualno razvijanje, ni samo izobraževanje, pač pa ga moramo gledati v njegovi celovitosti. / .../ Otrok živi v šoli v določenem kulturnem in socialnem prostoru, ki vpliva nanj in tudi on vpliva na to okolje. Zato je s svetovalnega vidika in vidika otrokovega razvoja pravzaprav nujno sodelovanje svetovalnega delavca s tem celotnim okoljem (fizičnim in socialnim) (Resman, 1999b, s. 68). Intervjuvanke kot svetovalne delavke poudarijo, kako nujno se jim zdi sodelovati z učitelji, ko nastopijo določene težave $\mathrm{v}$ razredu, pri posameznem otroku. Obenem prav vse kot dosti lažje označijo sodelovanje z učitelji razredne stopnje, predvsem zaradi njihove odprtosti, splošnejšega znanja, pripravljenosti za spreminjanje. Zdi se jim, da se ne čutijo ogroženi s strani šolske svetovalne službe v takšni meri kot predmetni učitelji. Stepišnikova (1998) je mnenja, da je kakovost dela šolskega svetovalnega delavca zelo odvisna tudi od učiteljev, saj so le-ti velikokrat njegova 'desna roka' pri izvajanju določenih novosti ali zamisli, zato je sodelovanje med njimi velikega pomena.

Pri učiteljih predmetne stopnje je opaziti pomanjkanje določenih znanj. Predvsem gre po mnenju intervjuvank za znanja s področja vzgoje in dela z otroki, skupinske dinamike, pomanjkanje samozavesti pri delu z otroki. V kolikor učitelji ta znanja imajo, si jih ne upajo uporabljati. Predmetne učitelje označujejo kot specialiste za določeno področje, nimajo pa splošnih znanj. Lahko da izhajajo tovrstne pomanjkljivosti tudi iz same izobrazbe predmetnih učiteljev (vsi se ne izobrazijo v okviru Pedagoške fakultete, ki daje določeno širino znanj o razvoju otroka in delu z njim, nakar so razredni učitelji prav vsi 
deležni poleg specialističnih znanj tudi splošnih psiholoških in pedagoških znanj). Resman (1999a) podobno opaža, da se učitelji o določenih temah v dodiplomskem študiju premalo usposabljajo. Učitelji niso dovolj usposobljeni za obvladovanje socialnih odnosov, usmerjanje in svetovalno delo z učencem, sodelovanje $\mathrm{z}$ domom in starši itd. Teh veščin se učitelji pogosto šele 'priučujejo', šele ko se znajdejo pred problemi, pogosto tako, da prevzemajo načine reševanja, kot jih uporabljajo njihovi starejši kolegi, kar pa ni vedno najbolj uspešno.

Spol otroka vpliva na kaznovanje.

Na pogostost in način kaznovanja vplivajo različni dejavniki. Sem sodijo dejavniki, povezani z učencem (npr. spol učenca) ter tisti, ki opredeljujejo učitelja in njegovo odzivanje na dražljaje iz okolice (npr. delovna doba in učiteljeva osebnost). Intenziteta ter oblika zaznanih kazni je povezana $\mathrm{z}$ vplivom spola na kaznovanje. $\mathrm{V}$ kolikor spol v očeh svetovalnih delavk ne bi vplival na pogostost kaznovanja, tudi svetovalne delavke določenih kazni ne bi zaznavale v tolikšni meri, kot jih dejansko zaznavajo. Zaznavajo pa jih "spolno obarvano". Ko učitelj kaznuje učenca in za to izve svetovalna delavka, si oblikuje mnenje, kateri spol je pogosteje kaznovan.

Intervjuvanke ugotavljajo, da so fantje pogosteje kaznovani kot dekleta, vendar težko ocenijo ali je sam spol tisti vzrok ali bolj spolno pogojeno vedenje (fantje so bolj živahni, nemirni), zaradi katerega so pripadniki določenega spola bolj opaženi, moteči in zato pogosteje kaznovani.

McManus (1990) ugotavlja, da so dekleta slabo zastopana v statistikah šolskega kaznovanja. Pravi, da so obravnavane kot da povzročajo manj težav kot fantje. Ugotavlja, da v primeru, da ta trditev drži, to ni posledica ubogljivosti, temveč strateške prilagoditve situaciji. Agresivnost se dekletom ne izplača tako kot se nekaterim fantom. Dekleta si izberejo bolj učinkovito strategijo, ki se prilega socialnim in kulturnim pričakovanjem okolice. Čeprav se navadno zanika dvojnost meril pri obravnavanju deklet in fantov, šole velikokrat uporabijo prav spol kot klasifikacijo za delitev. V tem smislu je biološka kategorija spola pretvorjena v sociološko kategorijo. Ko je enkrat narejen ta korak, je zelo verjetno, da bo prišlo do razlikovanja $\mathrm{v}$ ciljih in strategijah deklet in fantov. Daviesova (po McManus, 1990) izpodbija prepričanje, da so dekleta manj deviantna v šo- li ter namiguje, da je njihova deviantnost enako velika, le da zavzema drugačne oblike. Dekleta so konformna le na določenih področjih - upoštevajo institucionalna pravila v smislu obiskovanja pouka, lepega vedenja ter nepovzročanja materialne škode. Prav slednja vedenja pa so za področje raziskave pomembna.

Ravnatelji se aktivno vključujejo v reševanje težav.

Šolske svetovalne delavke imajo pomembno vlogo v procesu kaznovanja, saj prinašajo drugačen, strokoven in neodvisen pogled na otroka, učitelja, prekršek in samo kazen. Pomembna pa je tudi vloga ostalih akterjev: učiteljev, vodstva in staršev. Vlogo slednjih močno definira prav šolska svetovalna služba, saj jih ponavadi ona povabi k sodelovanju. Intervjuvanke svojo vlogo vidijo kot svetovalno in ker kot tretja oseba ponavadi dejansko niso vključene v konflikt predstavljajo neodvisno osebo. Tako pedagoginja, socialna pedagoginja kot tudi psihologinja pravijo, da se vodstvo šole aktivno vključuje v reševanje težav. V kolikor se ne vključijo sami, jih spodbudijo one.

Izobrazba ravnatelja vpliva na šolsko kaznovalno politiko.

Po mnenju Bezićeve (1996) so vodilni delavci tisti, ki določajo kulturo celotne organizacije. Predvidevam, da je prav svetovalni temelj, ki so si ga vodstveni delavci tekom dodiplomskega izobraževanja pridobili ali pa tudi ne, tisti, ki pomembno vpliva na način sodelovanja in vodenja. Intervjuvanke imajo izkušnjo z različnimi strokovnimi profili vodstva. V splošnem opažajo pozitivne učinke, v kolikor ravnatelj izhaja iz vrst profilov, ki deluje v okviru šolske svetovalne službe. Zdi se, da se v takih primerih nagiba k večjemu delu na strokovni obravnavi otrok, ki imajo težave in pomoči učiteljem, ki imajo težavo z disciplino v razredu. Politika kaznovanja v šoli je pomembno odvisna od usmerjenosti, strokovnega pedagoškega, psihološkega znanja vodstva šole.

\section{Zaključek}

Kaznovanje je še vedno del šolskega postopanja o katerem se nerado govori, tudi se ga premalo raziskuje $z$ vidika treh pomembnih šolskih podsistemov: učencev, učiteljev in svetovalnih delavcev. Odzivi so temu primerno obrambni. Realnost nas opominja, naj ne pozabimo tega 
zamolčanega dela vzgoje in izobraževanja, saj še vedno obstaja v šoli telesna kazen, še vedno učitelji sramotijo učenca pred sošolci, še vedno marsikateri učenec zapusti učilnico... Učinkovitost tovrstnega vzgojnega postopanja je vprašljiva. Učitelji, katerih poklic vsekakor ni lahek, zatrjujejo, da manjkrat kaznujejo kot pravijo učenci. Kje najti resnico? Je resnic več? Je resnica nekje vmes?

Svetovalna služba, lahko pomaga najti odgovor na vprašanja. A obenem se nam zastavlja vprašanje profesionalnosti, (ne)ustreznosti pristopov, slaba izobraženost...

Zaupanje učencev in učiteljev v svetovalno službo je dokaj majhno. Zdi se, da predstavniki šolske svetovalne službe pod kopico dela, ki jim je naloženo, nekako ne najdejo časa za "delo na terenu". V kolikor pa si prizadevajo za prisostvovanje pri pouku, se s tem ne strinjajo učitelji. Zdi se, da so predmetni učitelji slabše usposobljeni, manj samozavestni pri vzgajanju, večkrat nestrokovno reagirajo na učenčeve provokacije in se, na žalost, po mnenju intervjuvanih svetovalnih delavk, večkrat počutijo ogrožene s strani svetovalne službe.
Pozitivne spremembe šolske klime vidiva prav v poudarku na izobraževanju predmetnih učiteljev na področju vzgoje in dela z učenci že med samim študijem. Vodstvo naj bi omogočalo izobraževanje učiteljev tudi tekom zaposlitve. Ravnatelji, ki izhajajo iz vrst svetovalnih delavcev, so strokovno podkovani za delo $\mathrm{z}$ otroki in imajo praviloma zanje več posluha, zato je primerno spodbujati tovrstni profil za udejstvovanje v vodstvenih funkcijah. Pristop svetovalnih delavcev pa naj bi bil bolj operativen.

In kako naj bi učitelji, svetovalni delavci, vodstvo ter nenazadnje starši postopali z učencem, ki krši pravila? Restitucija se zdi dober način discipliniranja, če se le ne sprevrže v prikrite oblike manipulacije in nevidne načine psihičnega kaznovanja. Vsekakor si otroci želijo in zaslužijo primeren odnos tudi v šoli. Walters (1990) pravi, da je bila v petdesetih letih narejena študija o glavnih svetovnih religijah in našli so samo eno, vsem skupno točko. Vse vere uče eno od različic življenjskega pravila: "Stori drugim, kar želiš, da drugi store tebi". Po tem bi se lahko zgledovali vsi, ki delajo z živimi bitji.

\section{I T E R A T U R A}

- Bezić, T. (1996). Ravnatelj (vodstvo šole) in šolska svetovalna služba. V: Rupar, B., Počervina, L. (ur.). Posvet profesionalizacija šolskega svetovalnega dela. Portorož: Zveza društev pedagoških delavcev, Sekcija šolskih svetovalnih delavcev.

- Chelsom Gossen, D. (1993). Restitucija: preobrazba discipline v šolah. Radovljica: Regionalni izobraževalni Center.

- Coloroso, B. (1996). Otroci so tega vredni. Ljubljana: Tangram.

- Gibson, J. T., Chandler, L. A. (1988). Educational psychology: mastering principles and aplications. Boston: Allyn and Bacon.

- Gogala, S. (2005). Izbrani spisi. Ljubljana: Društvo 2000.

- Gray, P. idr. (1994). Challenging behaviour in schools: an introduction. V: Gray, P. idr. (ur.) Challenging behaviour in schools: teacher support, practical techniques and policy development. London, New York: Routledge.

- Hauck, P. (1988). Uspešna vzgoja otrok. Ljubljana: Mladinska knjiga.

- Kroflič, R. (1997). Avtoriteta v vzgoji. Ljubljana: Znanstveno in publicistično središče.

- Kroflič, R. (2003). O pedagoški vrednosti kazni. Šolska kronika, 12 (2).

- Kroflič, R. (2002). Šola - izkustveni prostor socialnega učenja in / ali moralne vzgoje? Sodobna pedagogika, 53 (119), št. 5.

- McManus, M. (1990). Troublesome behaviour in the classroom: a teacher's survival guide. London: Routhledge.

- Mendler, A. N. (1992). What Do I Do When...?: how to achieve discipline with dignity in the classroom. Bloomington: National Educational Service.

- Pravilnik o pravicah in dolžnostih učencev v osnovni šoli (1996). Uradni list RS

- Puhar, A. (2004). Prvotno besedilo življenja. Ljubljana.: Studia humanitatis.

- Resman, M. (1996). Profesionalizacija šolskega svetovalnega dela. V: Rupar, B., Počervina, L. (ur.). Posvet profesionalizacija šolskega svetovalnega dela. Portorož: Zveza društev pedagoških delavcev, Sekcija šolskih svetovalnih delavcev.

- Resman, M. (1999a). Oddelek, učitelj in svetovalni delavec. V: Resman, M. (ur.). Svetovalno delo v vrtcih, osnovnih in srednjih šolah. Ljubljana: Zavod Republike Slovenije za šolstvo.

- Resman, M. (1999b). Pojem in karakteristike šolskega svetovanja. V: Resman, M. (ur.). Svetovalno delo v vrtcih, osnovnih in srednjih šlah. Ljubljana: Zavod Republike Slovenije za šolstvo.

- Salecl, R. (1991). Disciplina kot pogoj svobode. Ljubljana: Krt.

- Skalar, V. (1978). Kazen v vzgoji. Ptički brez gnezda, 4 (13).

- Steiner, T. idr. (2004). Mala knjiga za velike starše: priročnik za vzgojo otrok. Ljubljana: Mladinski dom Jarše.

- Stepišnik, P. (1998). Kaj učitelji pričakujejo od šolskega svetovalnega delavca?. Šolsko svetovalno delo, 3 (1).

- Strmčnik, F. (1965). Analiza šolskih kazni. Ljubljana: Državna založba Slovenije.

- Svetovalna služba v osnovni šoli: programske smernice: osnutek. (1998). Ljubljana: Državni izpitni center.

- Walters, J. D. (1990). Vzgoja za življenje. Celje: Mohorjeva družba. 


\title{
Mitja Krajnčan, Nina Stenko
}

\section{PUNISHMENT IN SLOVENE ELEMENTARY SCHOOLS}

\begin{abstract}
Summary
The article offers a critical view on punishment, an always hot topic at school. School punishment is observed from a historical point of view, especially since the period when punishment became more humane. The question of the reasonableness of punishment and its appropriateness or necessity is the main issue of theoretical discourse. Restitution is seen as a good approach to punishment, without which it is difficult to imagine suitable socialization in a school environment, which should be an important challenge of postmodern schools.

The research also establishes how punishment appears in Slovene elementary school, if it even does, and what types of punishment prevail; what reasons for punishment are ascribed by pupils, teachers and by social workers. In dealing with punishment measures, we focused on the division of punishment types by Strmčnik (the category of administrative, morally condemning, settling, restraining, verbal and physical punishments), as well as on the efficacy of mentioned punishments.

We have performed interviews with social workers, trying to include also their role and point of view within the punishment dynamic and punishment in elementary school.
\end{abstract}

Key words: Punishment, elementary school, restitution, discipline, pupil, teacher. 